\title{
Glocalized telenovelas and national identities
}

\section{A 'textual cum production' analysis of the 'telenovelle' Sara, the Flemish adaptation of Yo soy Betty, la fea}

Fien Adriaens \& Daniel Biltereyst

\begin{abstract}
This article examines the globalization of the telenovela format in relation to issues of adaptation, proximities and national identities. As a case study of glocalized telenovelas, it deals with the domestic adaptation of one of the most popular Latin American telenovelas, Yo soy Betty, la fea (1999-2001) into the 'telenovelle' Sara (2007-08), which takes place in a Belgian (more specifically Flemish) context. Therefore, this article specifically asks how Flemish identities are represented through the production process of Sara. While examining the international flow of telenovelas and the cross-cultural adaptation of the telenovela format, this case study considers an additional geopolitical and cultural context, as well as confronts and combines thematic textual analysis with expert interviews. Considering the successful export of 'canned' telenovelas and the adaptation of this format within the framework of national identity and identification, this paper deals with the emergence of the 'telenovelle' as a local genre that is inspired by, and modifies, the Latin American original format.
\end{abstract}




\section{Introduction}

This article focuses on the globalization of the telenovela format in relation to issues of adaptation and national identities. It deals with the question of how the telenovela format is successfully adapted to regions outside Latin America, particularly in Western Europe. Since a television format's success is closely tied to the local and national culture, and domestic television programs play a crucial role in the construction and reproduction of national identities (Biltereyst, 1991; Straubhaar, 1991; Waisbord, 2004), we question whether and how national identities are represented through production decisions in the creation process. As a case study, we will focus on Belgium's adaptation of a popular Latin American telenovela, Yo soy Betty, la fea (1999-2001), particularly in the northern Dutch-speaking part of the country, Flanders. ${ }^{1}$ The original Yo soy Betty, la fea, produced by the Colombian Radio Cadena Nacional (RCN), was an immediate sensation in its domestic market and quickly gained popularity in the rest of Latin America, the USA and elsewhere. In total, Yo soy Betty, la fea was adapted in nearly 20 American, Asian and European countries. In Flanders, as in many other European countries, original versions of telenovelas have regularly appeared on television since the 1980s (Biltereyst \& Meers, 2000: 400). Therefore, the local adaptation of Yo soy Betty, la fea (as Sara) was quite exceptional for two reasons: a) the local producers and channels had never used an existing telenovela format as a starting point for developing a domestic fiction, and b) the adaptation was an immediate success.

This case study on the adaptation of the original Colombian format into the successful Flemish 'telenovelle' $\mathrm{Sara}^{2}$, will combine textual analysis with production analysis. By means of a 
thematic textual analysis, we will take a closer look at how national identities were represented in Sara, which was produced for and broadcast by the commercial channel, Vlaamse Televisie Maatschappij $^{3}$ (VTM, 2007-2008). To understand the production choices made during the adaptation process, we conducted several in-depth expert interviews with Sara's head of scriptwriting, Hugo Van Laere. This 'textual cum production analysis' was designed to respond to the lack of comprehensive studies on text and production as crucial sites of meaning making (Tufte, 2000; Acosta-Alzuru, 2003b). This analysis is also inspired by Robert Stam's reformulation of a meaningful sociology of adaptation, which is seen "as a kind of multi-leveled negotiation of intertexts" (Stam, 2000: 67) where textual as well as industry analysis can be incorporated. This analysis is part of a broader project on the successful local adaptation and audience reception of global formats like the telenovela, Yo soy Betty, la fea, in Flanders (Adriaens, 2010).

\section{Telenovelas, proximities and adaptation}

The telenovela format developed as a complex cultural product with generic, social and cultural roots that reach deep into Latin American history (La Pastina, 2004). The rise of radionovelas in the late 1930s in Cuba significantly influenced the proliferation of telenovelas in Latin America. Furthermore, Cuba facilitated the rising popularity of telenovelas throughout the 1950s in Latin America by providing actors, producers and screenplays, while advertising agencies and multinational corporations from the USA were active in disseminating the new format in the wider region. After the mid-1960s, the USA's direct control over the growth and expansion of telenovelas subsided and the genre gradually began to evolve in diverse directions in different countries. By the late 1960s, local production companies were writing their own stories, bringing 
in local influences, incorporating socio-cultural messages and shaping the narratives for particular audiences. During this time, TV networks increasingly used telenovelas to gain a larger share of the market and conquer new audiences. Although the telenovela format has a common history, it has evolved into a broad genre with highly diversified production methods from various Latin American production centers that contain noticeable differences in their use of themes, narrative styles and production values (Straubhaar, 2007: 152).

It is possible to categorize telenovelas - like soap operas - within the melodrama metagenre, which suggests an emphasis on strong pathos, heightened emotionality, moral polarization, nonclassical narrative mechanisms, spectacular effects and (often) stylistic excess (Singer, 2001: 7). Telenovelas as a broader genre are successful because they are easily exported to other cultures thanks to their underlying structure, formulas and archetypes that relate to many cultures (La Pastina \& Straubhaar, 2005). However, authors who specialize in the field of telenovela studies often indicate that, although their narrative structures are the same, telenovelas are different from US soap operas (e.g. Allatson, 2007; Lopez, 1995). In addition to differences in gender, class and race representations, they reflect different social and cultural needs and aspirations. Furthermore, telenovelas are financed by television networks, are broadcast in both prime time and afternoon blocks, and are primarily watched within a family context and targeted accordingly. Telenovelas determine the stardom system in Latin America, but unlike the soap opera system, the actors' identities are not fixed to the characters they portray, as they may perform in multiple telenovelas simultaneously (Acosta-Alzuru, 2003b: 194). Telenovelas are also dissimilar from soap operas in the opportunities that their viewers have to participate in the unfolding of the narration, for instance by suggesting alternative storylines. In terms of their narratives, telenovelas comprise a finite number of episodes (120-200 episodes), a climatic close and a clear end. Moreover, class 
conflict and social mobility are major themes within the telenovela discourse, while soap operas are less explicit on these issues. Other key characteristics of traditional telenovelas include: the presence of suspense and emotion, a heterosexual love story, the use of triangles, the forced bipolarity between good and evil, the significance of music in creating emotional identification, the use of actual events in the plot, natural acting and improvisation (Tufte, 2000; Acosta-Alzuru 2003; Allatson, 2007).

The top telenovela producers in the Latin American region currently include Televisa, Venevision and $\mathrm{O}$ Globo, which are the leading networks in Mexico, Venezuela and Brazil respectively. Recently, new players have gained power in the telenovela market such as Telefe in Argentina, $R C N$ and Caracol in Colombia, RCTV in Venezuela, Azteca TV in Mexico and Telemundo, which is aimed at the Spanish-speaking viewers in the US. These corporations dominate the media industries in their home markets and practice vertical and horizontal integration (Miller, 2010: 201). In the context of increasing globalization, these networks produce telenovelas for the domestic market and export them to other Latin American countries and the rest of the world. The export process can occur in three ways: a) as an original production in the original language, b) as a 'canned show', which presents the original production as dubbed or subtitled, or c) as an adapted and reproduced format for a new culture (Miller, 2010: 202). Canned telenovelas are popular in countries that have a similar geo-linguistic market (Sinclair, 1999) or cultural affinity (Straubhaar, 1991), as well as in poor or smaller countries with limited production facilities (Biltereyst \& Meers, 2000). In most other cases, domestically produced content is preferred. Local adaptations may also appear because the audience has an aversion to dubbed or subtitled fare. La Pastina and Straubhaar (2005: 273) argue that audiences prefer television programs that are "closest, most proximate or most directly relevant to them in cultural and linguistic terms," 
which is related to the concept of cultural proximities ${ }^{4}$ (Straubhaar, 2007: 199). The latter enhances the audience's affiliation with the media content, as it culturally resonates with their everyday life experiences.

Locally produced telenovelas proliferated and expanded in an environment where television remained tied to national cultures, but media was subjected to globalization processes (Waisbord, 2004: 360; Waisbord \& Jalfin, 2009). National identities are crucial in the global process of telenovela trading (Beeden \& De Bruin, 2010), where "national identities are conceived as specific forms of social identities that are discursively, by means of language and other semiotic systems, produced, reproduced, transformed and destructed" (De Cillia \& Wodak, 1999: 153; Hall, 1996). To enhance the audience's receptiveness, domestically produced telenovelas are often inspired by existing Latin American telenovelas and adapted to local contexts (Curran \& Morley, 2006; Kraidy, 2005). In his book 'TV formats Worldwide', Albert Moran (2009a) attributes this localization tendency to diverse factors such as alterations in national television systems caused by privatization, deregulation, and the proliferation of novel distribution technologies, which have multiplied the availability of television channels within national spheres. Protectionist policies may also encourage producers to adapt their contents to local considerations such as employing domestic production personnel. Above all, language is the most powerful unifier and divider that forces media production to adapt imported contents to the needs of the audience (Waisbord \& Jalfin, 2009: 58).

The concept of localization allows us to discuss four distinct processes (Waisbord \& Jalfin, 2009: 57). First, localization has been absorbed in the neologism 'glocalization' (Robertson, 1995), which refers to the interaction between global and local factors that result in distinctive outcomes 
in different geographical areas (Straubhaar, 2007; Paxman, 2003). Here, two processes are included: the flexibility of the global media market to integrate local factors and the ability to articulate local contents in global ideas. Secondly, localization has been used as a synonym for 'domestication' or customization of international content. Thirdly, localization refers to processes of 'cultural hybriditization', a concept derived from postcolonial theory that indicates a genuine synthesis of diverse cultural elements into a new hybrid culture. The globalization of media has accelerated processes of cultural hybridization around the world by providing opportunities for individuals to encounter media content that is produced outside their cultural environments (Martin-Barbero, 2006; Straubhaar, 2007: 12; Kraidy, 2002, 2005). Fourth, localization points out the power that domestic media industries hold amidst the increasing intricacy of media flows and global economies. The growth and consolidation of 'local champions' is a vehicle for the development of multilayered media flows (Straubhaar, 2007). In creating a 'local champion,' Moran (2009a: 50) stresses the significance of a wide variety of cultural proximities such as language, ethnicity, history, religion, geography and culture that allow for the adaption of the original series into a local version that takes into account communal and national differences. Gender relations and public behavior are additional areas of cultural sensitivity that must be considered in adaptations of television shows. In the specific case of telenovelas, La Pastina and Straubhaar (2005) point out several cultural components that characterize a local focus such as dress codes, ethnic types, body language, humor, ideas about story pacing, music, religious elements etc. However, the success or failure of a localized adaptation lies not in the process of remaking the show, but in the local audience's process of recognition, identification and appreciation (Moran, 2009a: 52). 
In their study on the adaptation of imported programming in Argentina, Waisbord and Jalfin (2009) examine how television gatekeepers construct images of national audiences and how those images inform decisions within the business constraints of the industry. They argue that the localization of foreign formats suggests that 'the nation' is constructed and imagined, and represents a dynamic collective actor with shared social, economic and political experiences that determine specific cultural characteristics. Localization signals the role of television as a type of 'banal nationalism' (Billig, 1991), a social institution that offers daily, invisible reminders of national bonds and shared experiences. This invisibility is precisely the goal of strategies aimed at adapting foreign programs into local, authentic products. Moran (2005: 123) argues that the "kinds of mundane, taken-for-granted representations of the nation that are found in particular incarnations of TV program formats are the means by which the nation is reproduced as a hegemonic form." Domestic TV programs frequently make use of national identity discourses, which reiterate national stereotypes and myths about the national character. They endeavor to be recognizable and to create a sense of authenticity and truthfulness. In a Flemish context, Dhoest (2001) argues that hegemonic discourses about the region generally refer to the traditional peasant culture, to which particular 'Flemish' values are attached such as conservatism, simplicity, virtuousness and industriousness.

Authors working in the field of telenovela studies argue that the genre's success is linked to its intrinsic 'formula' that usually comprises stories with universal appeal (such as rags-to-riches and Cinderella stories) and globally resonant archetypes with which viewers can easily identify. Telenovelas are typically stories that are told to a national audience using a melodramatic method (Acosta-Alzuru, 2003b; Miller, 2010:213). The cultural aspects of the telenovela are often closely tied to economic aspects, such as cost-competitiveness and the capacity to attract loyal viewers. 
While telenovelas are localized products that are primarily produced to achieve domestic success, the cross-ownership structure and multinational flows that characterize the telenovela industry render any conception of telenovelas as South-to-North cultural contra-flows inherently problematic (cf. Bielby \& Harrington, 2005 on the telenovelization of soaps in US). Rather, it is best to understand telenovelas as localizable yet universally appealing cultural products that traverse the global networks of capitalist cultural concerns (Miller, 2010). The original broadcastversion of Yo soy Betty, la fea (1999-2001), for instance, was exported as a finished economic product and as a cultural formula to virtually every Latin American country (Moran, 2009b: 1029; see also Miller, 2010: 213). Dubbed or subtitled versions have been broadcast in several media markets including those in Bulgaria, Brazil, China, the Czech Republic, Georgia, Hungary, Italy, Japan, Malaysia, Mexico, Poland, Spain, Turkey and many other Asian and European countries (Akass \& McCabe, 2007; Moran, 2009a). Its massive popularity has led to adaptations in nearly 20 countries, including India, Turkey, Russia and Germany (Verliebt in Berlin, Sat 1, 2005), as well as in the USA (Ugly Betty, ABC, 2006) and Flanders (Sara, 2007). Apart from successful corporate strategies for production, distribution and marketing, the international circulation of $Y o$ soy Betty, la fea is largely related to the universal themes and culturally adaptable characteristics of the Betty format. The story of a young woman of modest origin that accomplishes romantic and financial success against all odds serves as the universal Cinderella theme, while the dangerous city setting and the intimidating social frictions between urban fashionistas and those from monotonous middle-class or rural backgrounds, are features that have straightforward localization potential in the viewer's own culture.

The academic interest in the telenovela phenomenon, and the subsequent growth of the telenovela studies field (e.g. Antola \& Rogers, 1984; Vink, 1988; Martin-Barbero, 1993; McAnany \& La 
Pastina, 1994; Biltereyst \& Meers, 2000; Tufte, 2000; La Pastina, 2002, 2004; Acosta-Alzuru, 2003, 2004; Mayer, 2003; Stavans, 2010), are largely due to the international success of the telenovelas format, as well as arguments that point to a more complex media and cultural world order. In this debate, Betty, la fea is a strong example in support of contra-flow arguments (Moran, 2009b), which has led to a growing number of case studies that focus on the show's adaptation and reception, mainly in the American context (Akass \& McCabe, 2007; MolinaGuzman, 2011; Barriero, 2010; Esposito, 2009). This paper will extend this line of interest as a case study of contemporary glocalized and domestically adapted telenovelas, by focusing on their embeddedness in the Western European context. The Flemish adaptation of Yo soy Betty, la fea into Sara brings in another geopolitical and cultural context, while confronting and combining thematic textual analysis with expert interviews. The thematic textual analysis, performed on a sample of half of the episodes, was inspired by the adaptation model developed by Moran (2009a: 50) and by literature on textual analysis and processes of localization (e.g. MolinaGuzman, 2010; Amaya, 2010; Esposito, 2009, Miller, 2010; Barriero, 2010). The four expert interviews conducted with the head of the writing team were inspired by Waisbord and Jalfin (2009) and Mayer, Banks and Caldwell's (2009) 'Production Studies.' Furthermore, the series of interviews was designed to produce in-depth, high-quality data as each interview elaborated and built upon on the previous one in order to diminish face value.

\section{The adaptation and production of Sara}

As in other European countries, 'canned' telenovelas such as the Brazilian A Escrava Isaura (1976-77) appeared on Flemish television beginning in the 1980s, but never achieved widespread popularity (Biltereyst, 1990). However, due to the limited size of the Flemish market, adaptations 
and domestically produced telenovelas were only explored recently. This also resulted from the growing competition and the role that local television fiction played as a strategic tool in the battle between the public and commercial television networks. The production of 'Flemish' telenovelas began in 2004 with Emma, an original domestic production that was aired by the Flemish public broadcaster VRT (Vlaamse Radio- en Televisieomroep) and immediately failed, mainly due to its lack of 'credibility' and because its reputation as a 'low quality' series. Two years later, VTM responded with Sara, the adaptation of Yo soy Betty, la fea, which ran from September 2007 until June 2008 and had immediate success. The next year, VTM launched another domestic telenovela, Louislouise (VTM 2008-2009), which was an adaptation of the Argentinean telenovela Lalola (América TV 2007) that achieved limited success compared to the hit wonder Sara. Over the following years, VTM produced their own original telenovela series David (VTM 2009-2010) and Ella (VTM 2010-2011), all of which were inspired by telenovela formats. While the term 'telenovela' was unknown to the audience and the industry when Emma and Sara debuted, the generic term 'telenovelle' (Dutch for telenovela) is now widely accepted and used in Belgian culture, and represents the local variant of the genre. At the time of writing, VTM was still broadcasting Ella, and the public broadcaster had scheduled the airing of another successful 'telenovelle' series for children (Amika, VRT-Ketnet). From a genre theoretical perspective (Altman, 2004), the emergence and wider acceptance of the 'telenovelle' genre among producers, network executives and schedulers, as well as among critics and audiences (and the academic community, one might argue) is highly interesting, as it confirms the importance of the genre. In this context, it is also interesting that the development of the 'telenovelle' genre was closely linked to that initiatives of the commercial channels and their 
attempts to launch the concept in advertisements, newspapers and other editorial material related to the program..$^{5}$

In focusing on Sara and its adaptation and production processes, it is useful to first look at the series' source. The adaptation rights for the Colombian Yo soy Betty, la fea were acquired by the independent television production company, FremantleMedia Belgium, a subsidiary of FremantleMedia International, the content and production division of one of Europe's largest TV, radio, and production companies, RTL Group. The group owned the franchise rights to Betty in various European countries, including Belgium, the Netherlands (Lotte) and Germany (Verliebt in Berlin). Following Hugo Van Laere's direction, Sara was based on the original Colombian Betty, and was inspired by the successful German adaptation. In fact, Van Laere revealed in his first interview (Personal communication, June 17 2010) that the team decided to watch only a few episodes of Verliebt in Berlin, which inspired them to develop some characters, but that the actual adaptation was based mainly on Betty la fea for licensing reasons. Following the Colombian original, Sara tells the ugly duckling story of Sara De Roose, a young woman of modest Flemish descent who dreams of pursuing a career in the fashion industry where she is a pariah because of her physical appearance. As in the Latin American version (Rivero, 2003), Sara's wit, intelligence and integrity help her to succeed and win her boss's heart (Simon Van Wijck).

Sara was written by a team of six writers and two editors under the supervision of the production house FremantleMedia Belgium, which successfully sold the series to VTM. The series consisted of 198 episodes that were broadcasted on weekdays, mainly during primetime, and attracted $35 \%$ to $49 \%$ of the total television viewership. Accordingly, Sara was a very successful television 
program with high visibility, exponential media coverage and commercial success. It was rewarded with numerous awards (e.g. Best Flemish television program) and evoked a real Sarahype, including a Sara fan day and Sara commodities such as a perfume, wedding dress, clothing line, etc. A broad audience that crossed gender and age barriers emerged, as figures indicated that $62 \%$ of Sara viewers were female while $38 \%$ were male (see in this context: La Pastina, 2004). These figures represent all ages, but with $44 \%$ of the total share, the 55+ group was overrepresented, which was probably due to the early hour of broadcasting. When examining the figures related to social groups, the two lowest social groups were overrepresented. ${ }^{6}$ This is easily explained by considering the fact that lower-income social groups are one of VTM's target audiences (Centre for Information about the Media, email, May 10, 2010).

In his analysis of the adaptation of global TV formats, Albert Moran (2009b: 46-52) makes a distinction between three phenomena: a) 'linguistic-code' translation, which refers to the poetics of television in terms of the different specificities of form and style, b) 'intertextual-code' translation, which deals with adaptation according to local television production, technical or generic standard and c) 'cultural-code' translation, which refers to the localization of a format involving issues such as gender relations, history, language, geography, ethnicity, public behavior and cultural values at large. When asked about the Betty/Sara adaptation process and the relative freedom he and his writing team encountered, Van Laere claimed, " $60 \%$ of the original Colombian script was used and 40\% was created anew" (Personal communication, June, 17 2010). Van Laere's relatively wide liberty to transform the original Betty was largely related to the need to adapt the script to the Belgian/Flemish context and to generate identification and recognition among viewers. This is related to Moran's 'cultural-code' translation, which will be discussed in later sections. 
First, it is necessary to consider the results of the production analysis in terms of the linguisticand intertextual-code translation of Betty into Sara. One of the key findings was that the creative process of rewriting and retelling the original Betty story was subject to budget-related restrictions as well as specific guidelines imposed by the commercial broadcaster in terms of production values, scheduling and advertising practices. For instance, according to Van Laere, the narration of the telenovela was clearly structured around commercial breaks (two large breaks) and the hour of broadcasting (access primetime). In addition to marketing and publicity practices, the network explicitly referred to some of the success factors that contributed to other local series, such as narrative complexity, pace and the use of well-known local stars. The network did not want to copy the strategy of audience participation in the production and development of the story, as is often the case in Latin American telenovelas. Although Fremantle Media International supported the idea of audience participation, VTM wanted to be safe and shot the whole series in advance, thus removing the possibility for alternative storylines. In addition to the broadcaster's demands, other market logics such as product placement determined the development of the script. In the case of Sara, this only had slight implications, but subsequent telenovelas (e.g. David, Ella) were required to give market demands greater attention, as advertisers witnessed the success of Sara. For Van Laere (Personal communication, June 17 2010), product placement was only acceptable if there were no repercussions for the pace of the story and the consistency of the characters: "Product placement... If it doesn't hurt the story or credibility of the characters, it's fine by me, since it provides for extra budgets."

The adaptation process was also informed by the experiences of the other European Betty series, particularly the Dutch and German versions. When talking about the failure of Lotte in The Netherlands, Van Laere argued that this was mainly because the writers made significant changes 
to the original script, both in the story's narrative line and characters. Van Laere stressed that the original Colombian script was written intelligently, that the idea of Betty becoming the leader of two different worlds (the world of high fashion and the lower social classes) and the use of 'unity of opposites' were highly productive. Conversely, some storylines were simply incompatible with the Belgian/Flemish context, as well as with production values, or, in Moran's terms, to local 'linguistic' and 'intertextual' codes. Inspired by the German version, the scriptwriters decided to create new characters and increase the narrative's complexity. One recurrent factor that Van Laere repeatedly referred to in interviews with newspapers and specialized magazines ${ }^{7}$ was that the Flemish Sara was a thoroughly reworked version, with higher production values, a quicker pace and more complex story lines than the original Betty had. This was closely related to the fact that Sara, which was introduced by some newspapers in rather pejorative terms as a "Flemish chocolate melodrama," ${ }^{8}$ was considered by VTM to be a sort of prestige project, thus illustrating the network's willingness to play an important role as a producer of domestic 'quality' fiction.

Van Laere argued that one of the most problematic issues was the lack of life stories of some of the characters in the original script. According to the head of Sara's writing team, these complex life stories were necessary to create an understanding of the characters' behaviors. One example is Patricia Fernandez' role (Lorna Paz), the unfriendly secretary in Yo soy Betty, la fea, who is considered a side-character and whose life story is not as visible compared to her equivalent, Britt, in Sara who is a valid protagonist with a detailed life story. Another significant change to the original script was the development of the story's pace. An original Betty, la fea episode contained seven scenes on average, resulting in a rather slow progression of the story, whereas a Sara episode consisted of approximately twenty scenes, which is standard for Flemish television fiction. 
Notwithstanding these changes, the textual analysis of Sara indicates that the love story, as in every traditional telenovela narrative, had a climatic close that referred to the gradual transformation of the protagonist, Sara, from an ugly insecure girl to a beautiful, confident woman. The series had a clear ending point that resulted in the marriage between the two main characters, Sara and Simon. In terms of the characters, bipolarity was crucial, specifically between 'good versus evil' Characters. While the 'good' characters (e.g. Sara, Hans, Leon) were clearly opposed to the 'bad' characters (e.g. Britt, Alexander, Koen), more complex or neutral characters were included in the story (e.g. Helena, Simon, Lieven). Furthermore, suspense and emotion were central characteristics of the narrative, as every episode ended with a cliffhanger that would encourage viewers to watch the next day. Emotion was evoked by different parameters, including the use of the voice-overs (Sara's voice telling her perspective on the story), soft-focuses, blurred images and romantic music underlining an emotional atmosphere (e.g. Sara's daydream scenes). There was a frequent use of Spanish and Portuguese music, which can be considered a reference to the original telenovela roots. In addition to the music, close-ups frequently enlarged the emotional effect. Therefore, Sara contained many references and was even quite faithful to the original telenovela format in terms of narration, atmosphere, the 'melodramatic' mode, character typology and character conflict construction. On the other hand, when one considers intertextuality and 'linguistic' codes, Sara made use of local methods of drama production in technical and narrative terms (pace, character complexity) where the writing team was inspired by or negotiated with other texts (or in Stam's terms 'intertexts') such as other Flemish series (e.g. the successful Wittekerke, VTM 1993-2008) and foreign Betty adaptations.

\section{Identification, recognition, credibility and markers of proximity}


This paper will now examine the 'cultural-code' translation, or the combination of social and cultural factors "that make for communal and national difference" (Moran, 2009b: 50) found in Sara's content. First, it is necessary to consider Van Laere's continuous reference to concepts such as recognition, credibility and identification. One might argue that the ease with which he referred to these concepts in interviews challenges the usual skeptical academic restraint in this regard, but we think it is necessary to include these production-led concepts in the analysis. The writers' central aims were to enhance identification and recognition with the series by portraying a 'credible image' of Flanders and Flemish identity. For Van Laere, this construction of a Flemish identity was unproblematic and concrete, as he states, "bringing our deaths to a crematorium or a church is typically Flemish, while burning our deaths on a woodpile as they do in Asia, is not" (Van Laere, personal communication, June 18, 2010). For him, the definition of identity was rather uncomplicated, highly concrete and sometimes even banal because it simply implicated "everything we know and recognize in everyday real life in Flanders" (Personal communication, June 18, 2010). Consequently, writers of telenovela adaptations try to assess 'banal nationalism' pragmatically by stressing the program's authenticity and credibility (Waisbord \& Jalfin, 2009: 69-70). In order to provide credible or 'realistic' events, characters or storylines that fit a local context, Van Laere and his team talked with a large number of people and built up the story while drawing inspiration from the real life stories and situations of Flemish people. In Sara, national identity or proximity markers ranged from the use of the local language (i.e. Dutch), to the choice of 'Sara' as the title of the series (the maiden name Sara ranked as one of the most popular in Flanders), to the series' location in a real Flemish city (Antwerp) and the fact that the audience is familiar with the actors. Furthermore, the local character of Sara was enhanced by numerous references to typical Flemish or Belgian services, 
products or culinary specialties such as French fries, beer, chocolate toffees, De Lijn (bus company), Q-music (a radio station affiliated with VTM), the use of classic Dutch-language names (Hans, An...) and so on. Furthermore, national stereotypes such as keeping your salary a secret, being modest, unpretentious and upright, maintaining a 'hard-working farmers' mentality' and so on (cf. Dhoest, 2001), were reproduced in the text and helped to (re)construct discourses of national identity and imagined community. All the characters in Sara were constructed as highly industrious and conscientiously devoted to their professions regardless of their social class. However, most of the markers of proximity were strongly interrelated. For instance, geography strongly influenced the characters, their gender roles and their public behaviors or values. The original version was situated in the capital of Colombia, Bogota, where crime rates are extremely high, and where Betty had an evening curfew, imposed by her protective parents. According to Van Laere, it was impossible to reconcile this Colombian context with Belgian society where crime rates are relatively low, cities are rather safe at night and where levels of education and female emancipation are relatively high. "In Belgium, we don't have dangerous cities like this and moreover, Sara is an adult woman who went to university. An evening curfew wouldn't have been credible" (Van Laere, personal communication, June 25, 2010).

Another marker that is also related to differences in the construction of characters, gender and public conduct, is the extreme focus on external beauty in Colombia and the introduction of plastic surgery in Betty, la fea. Following Rivero (2003: 66), notions of female beauty and ugliness are social constructions that relate to historical, social, economic and racial processes in specific cultural spaces. In a Eurocentric ideology, the beautiful female body is informed by whiteness, sexual constraint, body fitness and youth. Moreover, it is permeated by upper middleclass bourgeois codes of conduct and appearance (Rivero, 2003: 66). In this sense, Van Laere 
claims that referencing plastic surgery would not work for a Belgian audience since in this national context, plastic surgery practices are still considered less acceptable and ethically questionable in comparison to promoting positive body images. In fact, Van Laere (personal communication, June 26,2010 ) had personal objections against expressing a message that encouraged plastic surgery: "In a Colombian context, plastic surgery is a common thing to do. But, when I received the original script, I immediately said: 'I will not touch upon Sara'. Personally, I have nothing against plastic surgery, but I think it would be wrong to imply that anything can be solved by letting doctors change your body. That would be too easy." These markers of proximity or adjustments to national contexts and identities (language, geography, gender relations, history, ethnicity, cultural values) are easily interpreted as unproblematic and obvious venues in the producers' strategic search for credibility, authenticity and success. Nevertheless, the interviews revealed that the writers were highly aware of the dangers of reducing the complexity of the Flemish cultural and social reality, or at least of only constructing some parts of it. In this sense, Van Laere referred to the choice to stress the local language dialect from the Antwerp region, and to underexpose class differences. In this context, Van Laere referred to "hidden identification" beyond class boundaries, since every viewer has something that he or she was insecure about when it comes to physical appearance or life in general. Everyone feels like Sara at some point in life, Van Laere argued, especially because Western society celebrates outer beauty so much. Van Laere did not refer to 'class discourse' as a possible explanation for identification, although he agreed that it could play an important role since everyone faces financial problems and is subject to class distinctions at a some point in their life. Interestingly, VTM, which targets 'lower' social classes, explicitly requested that the writing team not stress the visible gap between rich and poor in the narration. This is why, according to 
Van Laere, the class distinction in Sara was not as obvious as in the original story. However, while the production team's intention was to avoid class conflicts, our textual analysis showed a clear representation of class discourse, class conflict and social mobility. Class differences were mainly represented through differences in material economical conditions as well as in immaterial situations such as human qualities, cultural capital, symbolic goods, societal status, aesthetics, taste and social lifestyle (e.g. Sara requires a loan to pay off her second hand car whereas Simon owns several fancy cars) (see Adriaens, 2010). There are many other examples that subtly illustrate how the scriptwriters tried to avoid highly politicized and conflict-laden social issues by sticking to a hegemonic discourse on Flemish identity, which stands for a middle-class, hard-working and peaceful society. Here, one might also refer to the absence of the complex Belgian language and political environment, the ignorance of 'ethnic' minority communities or the lacking reference to race or ethnicity problems.

Notwithstanding these numerous markers of proximity, and the story's lack of a more complex notion of identity and citizenship, Sara can also be understood as incorporating more 'transnational' features and themes (e.g. fashion industry, love drama, humor). As Van Laere continuously stressed, Sara was a universal tale that drove upon a melodramatic mode and entailed numerous possibilities for identification, entertainment and escapism. Sara's success among second-generation diaspora girls in Flanders presents a clear illustration of the potential to transgress cultural boundaries by playing upon wider themes, such as humiliation. An in-depth audience study of these groups emphasized the importance of the melodramatic mode (e.g. romantic love) and of recognizable social and family values (cf. the importance of the family), as well as the significance of the empowering message concerning professional, social and class mobility (Adriaens, 2010). 


\section{Conclusion}

This article examined the local adaptation of Yo soy Betty, la fea - a commercially successful telenovela that was exported internationally in dubbed and locally produced formats (Mato, 2005). Betty's success reconfirms the special role that Latin American telenovelas play in debates concerning transnational flows and power in the field of audiovisual culture, thereby underlining the practice of contra-flow, both in terms of dubbed and subtitled programs and formats. This paper extends this line of inquiry by emphasizing the importance of adaptations outside Latin America, and the emergence of local versions of the original telenovela genre, specifically the 'telenovelle' in countries such as Belgium and the Netherlands.

This case study on Betty's adaptation in a Western-European (specifically Flemish) context, combined textual and production analyses. This approach is fruitful, not only in better understanding the practicalities of the adaptation process, including the many choices involved in translating television series into different cultural environments. This approach also underlined the importance of politico-economic interests (e.g. those of the network), as well as how adaptation requires a complex 'intertextual' negotiation between the original telenovela, various other adaptations (e.g. the German and Dutch series), other successful series and various cultural codes.

As far as the globalization/localization debate is concerned, this case study stressed the use of obvious, 'banal' or 'hegemonic' regional markers of proximity (cf. multiple proximities) that facilitate recognition, identification and audience success. Sara, Betty's Flemish adaptation, clearly comprised local elements such as the setting, the local dialect, the use of archetypes, 
typical regional products, and so on. According to Sara's writer, it provided a non-essentialist 'Flemish identity,' by which he meant "everything that is credible in a Flemish context" (Van Laere, Personal communication, June 18, 2010). Following Billig (1991), the localization of telenovelas generates a sort of 'banal nationalism' in which the nation is reproduced in a hegemonic form. On the other hand, this paper revealed the attractive qualities of the melodramatic mode of the telenovelle/telenovela as well as universal grounds for identification (e.g. a clear love, a latent class discourse, the importance of the family). Sara can then be labeled a hybrid, 'glocalised' cultural product that provides a universal love story adapted to the audience's local culture, which has the ability to "extend debate beyond the fiction into the public arena" (Gledhill, 1997: 383; see also Mayer, 2003). Discourses in glocalised telenovelas that enhance identification possibilities are, thus, similar to those in original Latin American telenovelas (e.g. La Pastina, 2002 and 2004; Tufte, 2000), although there are clear variations in their representation and intensity of occurrence depending on the regional context and the production's demands.

\section{REFERENCES}

Acosta-Alzuru, C. 2003b. Tackling the issues: meaning making in a telenovela. Popular Communication, 1(4): 192-215.

Acosta-Alzuru, C. 2004. Beauty queens, machistas and street children: The production and reception of socio-cultural issues in telenovelas. International Journal of Cultural Studies, 13(2): 185-203. 
Adriaens, F. 2010. The glocalized telenovela as a space for identifications for diaspora girls in Flanders. An audience cum content analysis of Sara. OBS* Observatorio, 4(4): 171-195.

Akass, K. \& McCabe, J. 2007. Not so ugly: Local production, global franchise, discursive femininities, and the Ugly Betty phenomenon. Flow TV, 5(7) retrieved from www.flowtv.org.

Allatson, P. 2007. Key terms in latino/a cultural and literacy studies. Oxford: Blackwell.

Altman, R. (2004). 95 theses about film genre. In Film/TV/genre, edited by D. Biltereyst \& P. Meers, 31-58. Gent: Academia Press.

Amaya, H. 2010. Citizenship, diversity, law and Ugly Betty. Media, Culture and Society, 32(5): 801-817.

Antola, L. \& Rogers, E. M. 1984. Television flows in Latin America. Communication Research, 11(2): 183-202.

Barriero, P. 2010. Understanding Ugly Betty: Negotiating race in a culturally-mixed text. Divergencias. Revista de Studios Linguisticos y Literarios, 8(1): 34-40.

Beeden, A. \& De Bruin, J. 2010. The Office: Articulations of national identity in television format adaptation. Television \& New Media, 11(1): 3-19. 
Bielby, D. \& Harrington, L. 2005. Opening America? The telenovela-ization of U.S. soap operas. Television \& New Media, 6(4): 383-399.

Billig, M. 1995. Banal nationalism. London: Sage.

Biltereyst, D. 1990. As telenovelas e o publico flamengo. Intercom: Revista Brasiliera de Comunicaçao, 13(62-63): 81-95.

Biltereyst, D. 1991. Resisting American hegemony: A comparative analysis of the reception of domestic and US fiction. European Journal of Communication, 6(4): 469-497.

Biltereyst, D. \& Meers, P. 2000. The international telenovela debate and the contra-flow argument: a reappraisal. Media, Culture and Society, 22(4): 392-413.

Curran, J. \& Morley, D. 2006. Media \& cultural theory. London: Routledge.

De Cillia, R., Reisigl, M. \& Wodak, R. 1999. The discursive construction of national identities. Discourse \& Society, 10: 149-173.

Dhoest, A. 2001. National identity as normality: Representation and typing in Flemish television fiction. Intersections: The Journal of Global Communications and Culture, 1(2): 15-26.

Esposito, J. 2009. What does race have to do with Ugly Betty?: An analysis of privilege and postracial representations on a television sitcom. Television \& New Media, 10(6): 521-535. 
Gledhill, C. 1997. Gender and genre: the case of soap opera. In Representation: Cultural representations and signifying practices, edited by S. Hall, 337-386. Open University Press, London.

Hall, S. 1996. Introduction: Who needs identity? In Questions of cultural identity, edited by S. Hall and P. Du Gay, 29-44. Thousand Oaks: Sage.

Kraidy, M. 2002. Hybridity in cultural globalization. Communication Theory, 12(3): 316-339.

Kraidy, M. 2005. Hybridity, or the cultural logic of globalization. Philadelphia: Temple University Press.

La Pastina, A. C. 2002. The sexual other in Brazilian television. International Journal of Cultural Studies, 5(1): 83-99.

La Pastina, A. C. 2004. Telenovela reception in rural Brazil: Gendered readings and sexual mores. Critical Studies in Media Communication, 21(2): 162-181.

La Pastina, A. C. \& Straubhaar, J. D. 2005. Multiple proximities between television genres and audiences. The schism between telenovelas' global distribution and local consumption. Gazette: The International Journal of Communication Studies, 67(3): 271-288.

Lopez, A. 1995. Our welcomed guests: Telenovelas in Latin America. In To be continued: Soap operas around the world, edited by R. C. Allen, 256-275. London: Routledge.

Martin-Barbero, J. 2006. A Latin American perspective on communication/cultural mediation. Global Media and Communication, 2(3): 279-297. 
McAnany, E. \& La Pastina, A. 1994. Telenovela audiences: A review and methodological critique of Latin American research. Communication Research, 21: 828-849.

Mayer, V. 2003. Living telenovelas/telenovelizing life: Mexican American girls' identities and transnational telenovelas. Journal of Communication, 53(4): 479-495.

Mayer, V. , Banks, M. J. \& Caldwell, J. T. Eds. 2009. Production studies: Cultural studies of media industries. New York: Routledge.

Mato, D. 2005. The transnationalization of the telenovela industry, territorial references, and the production of markets and representations of transnational identities. Television \& New Media, 6(4): 423-444.

Miller, J. 2010. Ugly Betty goes global: Global networks of localized content in the telenovela industry. Global Media \& Communication, 6(2): 198-217.

Molina-Guzman, I. 2010. Globalizing television: Ugly Betty and the American dream. Paper presented at the annual meeting of the International Communication Association, Suntec Singapore International Convention \& Exhibition Centre, Suntec City, Singapore, June 21, 2010.

Moran, A. 2005. Global franchising, local customizing: the cultural economy of TV program formats. Continuum: Journal of Media \& Cultural Studies, 23(2): 115-125.

Moran, A., ed. 2009a. TV formats worldwide. Localizing global programs. Bristol and Chicago: Intellect.

Moran, A. 2009b. New flows in global TV. Bristol and Chicago: Intellect. 
Paxman, A. 2003. Hybridized, glocalized and hecho in México: Foreign influences on Mexican TV programming since the 1950s. Global Media Journal, 2(2). Retrieved from: http://lass.calumet.purdue.edu/cca/gmj/sp03/gmj-sp03-paxman.htm

Porto, M. 2011. Telenovelas and representations of national identity in Brazil. Media, Culture \& Society, 33(1): 53-69.

Rivero, Y. 2003. 'The performance and reception of televisual "ugliness" in Yo soy Betty, la fea. Feminist Media Studies, 3(1): 65-81.

Robertson, R. 1995. Globalization: Time-space and homogeneity-heterogeneity. In Global Modernities, edited by M. Featherstone, S. Lash and R. Robertson, 25-44. Thousand Oaks, CA: Sage.

Sinclair, J. 1999. Latin American television: A global view. Oxford: Oxford University Press.

Singer, B. 2001. Melodrama and modernity. New York: Columbia University Press.

Stam, R. 2000. Beyond fidelity: The dialogics of adaptation. In Film adaptation, edited by J. Naremore, 54-76. New Brunswick, NJ: Rutgers University Press.

Stavans, I. 2010. Telenovelas. Santa Barbara, California: Greenwood.

Straubhaar, J. 1991. Beyond media imperialism: Asymmetrical interdependence and cultural proximity. Critical Studies in Mass Communication, 8: 39-59.

Straubhaar, J. 2007. World television: from global to local. Thousand Oaks, CA: Sage. 
Tufte, T. 2000. Living with the Rubbish Queen. Telenovelas, culture and Modernity in Brazil. Luton: University of Luton Press.

Vink, N. 1988. The telenovela and emancipation. A study on TV and social change in Brazil. Amsterdam: Royal Tropical Institute.

Waisbord, S. 2004. McTV- understanding the global popularity of television format. Television \& New Media, 5(4): 359-383.

Waisbord S. \& Jalfin, S. 2009. Imagining the national: Television gatekeepers and the adaptation of global franchises in Argentina. In TV formats worldwide, edited by A. Moran, 55-78. Bristol and Chicago: Intellect.

${ }^{1}$ Flanders is no independent state, but can be called a 'subnation' in the Belgian context because of its regional independence on a wide series of political, economical and cultural issues. Flanders has a surface area of $13,522 \mathrm{~km}^{2}$ and a population of 5.9 million (60\% of the Belgian population). The main language and cultural background of the southern part of Belgium, which is not included in this study, is French. Although Flanders cannot be called a 'nation,' we still choose to use the discursive concept of national identity.

\footnotetext{
${ }^{2}$ Sara consisted of nearly 200 episodes.
} 
${ }^{3}$ VTM is the largest commercial television network in Flanders, launched on February 11989 as the first commercial broadcaster. The network is owned by the holding VMMa, which holds different commercial networks (e.g. 2BE, Vitaya, Jim TV). VTM strongly emphasizes the Flemish character of its own productions.

${ }^{4}$ Cultural proximity operates not only on (supra)national levels but also within subnational and regional spheres. Moreover, multiple levels of cultural proximity need to be recognized including: genre proximity, cultural shareability, thematic proximity, value proximity etc. (La Pastina \& Straubhaar, 2005).

${ }^{5}$ See for instance articles like 'Vuistregels voor de echte telenovelle' (literally: 'Rules of thumb for the real 'telenovelle'), Knack, 16-09-2009, p. 53.

${ }^{6}$ These figures are based on the education level and profession of the primary income provider of a family.

${ }^{7}$ Maes, Els, 'Af en toe moet je alle ironie achterwege durven te laten' ('Sometimes, we need to drop the irony'), De Morgen, 22-09-2007, p. 23.

${ }^{8}$ De Backer, Jan (2009) 'De telenovelles zijn overal ter wereld aan opmars bezig. Ook Vlaamse zenders volgen de trend' ('Telenovelas are making their way up internationally, Flemish television is no exception'), De Standaard, 11-12-2006, p. 24. 